\title{
Effects of Foliar Application of Melatonin on Head Yield and Quality of Broccoli cv. Palam Samridhi
}

\author{
Mansha Gul, F.A. Khan, S.A. Bhat, S.A. Mir, A.A. Malik,
}

Amit Kumar, S. Narayan, Moinuddin, S.A. Lone

10.18805/IJARe.A-5915

\begin{abstract}
Background: Broccoli is a cruciferous vegetable with green flower buds. It has a reputation as a superfood as it is low in calories but contains a wealth of nutrients and antioxidants that support many aspects of human health. Broccoli is a good source of fibre and protein and contains iron, potassium, calcium, selenium and magnesium as well as the vitamins $A, C, E, K$ and a good array of $B$ vitamins including folic acid.

Methods: Thirty days old and uniform seedlings of broccoli cv. Palam Samridhi were transplanted in the field at a spacing of $45 \times 45$ $\mathrm{cm}$. Different concentrations of Mel, viz $0,20,40,60$ and $80 \mathrm{ppm}$ with three replications were sprayed at 15 days after transplanting (DAT). Head diameter, weight, chlorophyll and carotenoids, sugar, proteins and antioxidant were analyzed at harvest.

Result: Results showed that the maximum head diameter $(10.7 \mathrm{~cm})$, weight $(233.8 \mathrm{~g})$, chlorophyll $(0.79 \mathrm{mg} / \mathrm{g} . \mathrm{FW})$, carotenoid $(0.028 \mathrm{mg} /$ g.FW), phenol (178.1 mg/100 g DW), total antioxidant (362.3 mg GAE $100 \mathrm{~g} \mathrm{DW})$ and MSI (45.38 \%) levels were recorded with Mel $60 \mathrm{ppm}$. However, the highest levels of sugar $(129.0 \mu \mathrm{g} / \mathrm{g})$ and protein $(88.0 \mu \mathrm{g} / \mathrm{g})$ were recorded with Mel 80ppm followed by Mel $60 \mathrm{ppm}$.
\end{abstract}

Key words: Antioxidants, Broccoli sprout, Melatonin, Protein, Sugar.

\section{INTRODUCTION}

Broccoli [Brassica oleracea (L.) var. italica Plenk] is a relatively new vegetable for many Indians. It belongs to family Brassicaceae. Broccoli is an Italian word from the Latin brachium, meaning an arm or branch. The term sprouting as used in sprouting broccoli refers to the branching habit of this type, the young edible inflorescences often being referred to as sprouts. Broccoli has gained attention because of the struggles on patenting genotypes with high concentrations of glucosinolates showing positive effects in cancer treatment (Wolf et al., 2014). The sprouting broccolis are thought to have originated from the eastern Mediterranean then introduced into different parts of the world (Owis, 2015). The United States is the world's largest producer of broccoli. The flowers of broccoli are borne on a faceted floral shoot so that the inflorescence terminates the axis of the plant. The inflorescence, which has been described as a corymb, a corymbose panicle or a modified racemose panicle, consists of functional floral buds, perfect flowers, stem and bracts. At the time of harvesting, the inflorescence is a growing, faceted axis bearing a large number of immature, stalked flowers, floral buds and varied bracts which are smaller and simpler in form than the vegetative leaves. The bracts are absent from the terminal portion of the inflorescence (Buck, 1956; Gray, 1982).

Melatonin $(\mathrm{C} 13 \mathrm{H} 16 \mathrm{~N} 2 \mathrm{O} 2)$ is a low molecular weight organic compound ubiquitously available in almost all living organisms from bacteria to mammals and considered as the nature's most versatile biological signal (Pandi-Perumal et al., 2006). Chemically, melatonin is N-acetyl-5methoxytryptamine, an indolic compound derived from serotonin (5-hydroxytryptamine). Both biogenic amines are
Sher-e-Kashmir University of Agricultural Sciences and Technology of Kashmir, Shalimar-190 025, Srinagar, Jammu and Kashmir, India.

Corresponding Author: F.A. Khan, Sher-e-Kashmir University of Agricultural Sciences and Technology of Kashmir, Shalimar-190 025, Srinagar, Jammu and Kashmir, India.

Email: drkhan_387@skuastkashmir.ac.in

How to cite this article: Gul, M., Khan, F.A., Bhat, S.A., Mir, S.A., Malik, A.A., Kumar, A., Narayan, S., Moinuddin and Lone, S.A. (2022). Effects of Foliar Application of Melatonin on Head Yield and Quality of Broccoli cv. Palam Samridhi. Indian Journal of Agricultural Research. DOI: 10.18805/IJARe.A-5915.

Submitted: 11-09-2021 Accepted: 28-12-2021 Online: 28-01-2022

synthesized from the amino acid tryptophan through a well characterized biosynthetic pathway (Arnao and HernándezRuiz, 2014; Lee et al., 2015). Phytohormone IAA (indolyl-3acetic acid) bears some resemblance to melatonin since both are indole compounds and have a common biosynthetic pathway through the tryptamine in the tryptophan dependent IAA biosynthetic pathway.Melatonin has been reported to involve in regulating plant growth and development and especially play critical role (s) in plant defense systems (Weeda et al., 2014). The present investigation was carried out toinvestigatethe effectof foliar application of melatonin on improving head yield andquality attributes of broccoli.

\section{MATERIALS AND METHODS}

The investigation was carried out at the Division of Basic Sciences and Humanities, Faculty of Horticulture, SKUASTKashmir during the year 2017 and 18. One month old uniform 
and healthy seedling of broccoli cv. Palam Samridhi was collected from the nursery, Division of Vegetable Science (SKUAST-K) and transplanted at a spacing of $45 \times 45 \mathrm{~cm}$ in a well prepared field. Different concentrations of melatonin (Mel) viz 0, 20, 40, 60 and 80 ppm were sprayed through hand spray on the foliage of plants at 15 days after transplanting (DAT). One plot constituted one sample unit and each treatment consisted of four plots with 6 plants per plot.

Head diameter (at spherical) was measured by measuring tape then average of five plants was computed to get the mean head polar diameter. Head diameter (at spherical) was measured by measuring tape then average of five plants was computed to get the head equatorial diameter. After harvesting, five broccoli head were weighed at pan balance and average individual head weight was computed in terms of grams. Total yield of broccoli head sprouts from each plot was taken in kilogram and then, it was also converted to yield in quintal per hectare.

For total soluble sugar $100 \mathrm{mg}$ of dried sample was hydrolysed with $5.0 \mathrm{ml}$ of $2.5 \mathrm{~N} \mathrm{HCl}$ by keeping it in a boiling water bath for 3 hours. After cooling at room temperature the content was neutralized with solid sodium bicarbonate until effervescence ceases and volume was to $100 \mathrm{ml}$. Centrifuged the content at $500 \mathrm{~g}$ for 10 minutes and supernatant was collected. The amount of total soluble sugars was estimated by phenol sulphuric acid method (Dubois et al., 1956) colorimetrically. Extraction of protein was done by grinding $0.2 \mathrm{~g}$ of sample with $0.1 \mathrm{M}$ phosphate buffer (ph 7.5) in a mortar and pestle. Centrifuge it and use the supernatant for protein estimation (Bradford 1976). Bovine serum albumin (BSA) was used as protein standard. Total phenol was determined by spectrophotometeric measurement of blue colured complex by the reaction of phenols with phosphomolybdic acid in Folion Ciocalteur in alkaline medium (Bray and Thorpe, 1954). The total antioxidant capacity was measured by the method described by Prieto et al. (1999). The assay is based on the reduction of Mo (VI) to Mo (V) by the extract and subsequent formation of green phosphate/Mo (V) complex at acid $\mathrm{pH}$. Malondialdehyde (MDA) content generated as product of lipid peroxidation in the leaves of broccoli was estimated in different treatments according to Cakmak and Horst (1991). Leaf sample of $0.12 \mathrm{~g}$ were ground in $1.2 \mathrm{ml} 0.1 \%$ $(\mathrm{w} / \mathrm{v})$ trichloroacetic acid (TCA), then centrifuged at 12000 $\mathrm{g}$ for $10 \mathrm{~min}$. Then $0.3 \mathrm{ml} 0.5 \%(\mathrm{w} / \mathrm{v})$ thiobarbituric acid (TBA) was added to $0.3 \mathrm{ml}$ of the supernatant. The resulting mixture was boiled at $100^{\circ} \mathrm{C}$ for $20 \mathrm{~min}$. The reaction was stopped by placing the reaction tubes in an ice bucket. The absorbance values were measured at 532, 600 and $450 \mathrm{~nm}$. The interference of soluble sugars in the samples at $A_{532}$ and $A_{450}$ was corrected by subtraction. The MDA content ( $\left.\mu \mathrm{mol} \mathrm{g}{ }^{-1} \mathrm{FW}\right)$ was calculated according to the formula:

$$
\operatorname{MDA}(\mu \mathrm{mol} / \mathrm{g} \mathrm{FW})=6.45 \times\left(\mathrm{A}_{532}-\mathrm{A}_{600}\right)-0.56 \times \mathrm{A}_{450}
$$

Where,

$A_{532}, A_{600}$ and $A_{450}$ represent the absorbance of the mixture at 532,600 and $450 \mathrm{~nm}$, respectively.

The leaf membrane stability index (MSI) was determined according to the method of Premachandra et al. (1990) as modified by Sairam (1994). Leaf discs $(100 \mathrm{mg})$ were thoroughly washed in running tap water followed by washing with double distilled water. Thereafter, the discs were heated in $10 \mathrm{ml}$ of double distilled water at $40^{\circ} \mathrm{C}$ for 30 minutes. Then electrical conductivity $\left(C_{1}\right)$ was recorded by $E C$ (Electrical Conductivity) meter. Subsequently, the same samples were placed in a boiling water bath $(100 \mathrm{oC})$ for 10 minutes and their electrical conductivity was also recorded $\left(\mathrm{C}_{2}\right)$. The MSI was calculated as:

Membrane stability index $(\mathrm{MSI})=\left[1-\left(\mathrm{C}_{1} / \mathrm{C}_{2}\right)\right] \times 100$

The data recorded on various variables were statistically analysed by using technique of analysis of variance and significance was determined as given by Panse and Sukhatme (1967).

\section{RESULTS AND DISCUSSION \\ Physical characters of broccoli head}

Perusal of the data (Table 1) indicated that broccoli plant sprayed with $0 \mathrm{ppm}$ melatonin (control) showed the minimum polar as well as equatorial diameter of $7.1 \mathrm{~cm}$ and $6.5 \mathrm{~cm}$, respectively. However, there was significant improvement in polar as well as equatorial diameter of broccoli when sprayed with different doses of melatonin and Mel $60 \mathrm{ppm}$ resulted in maximum diameter of $11.6 \mathrm{~cm}$ and $10.4 \mathrm{~cm}$, respectively. The polar and equatorial diameter recorded with Mel $80 \mathrm{ppm}(10.7 \mathrm{~cm}$ and $9.5 \mathrm{~cm})$ was found at par with Mel $60 \mathrm{ppm}$. Mel 40ppm resulted in the second highest head diameter $(10.1 \mathrm{~cm}$ and $8.1 \mathrm{~cm})$ followed by $9.7 \mathrm{~cm}$ and 6.9 $\mathrm{cm}$ polar and equatorial diameter in Mel $20 \mathrm{ppm}$, respectively. Results further indicated that maximum individual head weight and yield (240 g and $1.9 \mathrm{~kg} / \mathrm{plot}$ ) was recorded with Mel 60ppm which was at par with Mel 80 ppm (233.8 $\mathrm{g}$ and $1.8 \mathrm{kh} / \mathrm{plot}$ ). The next highest head weight and yield $(221.5 \mathrm{~g}$ and $1.7 \mathrm{~kg} / \mathrm{plot})$ was recorded with Mel 40 ppm followed by Mel 20 ppm (208.1 g and $1.6 \mathrm{~kg} / \mathrm{plot}$ ) against the minimum head weight and yield $(199.9 \mathrm{~g}$ and $1.5 \mathrm{kh} /$ plot) in Mel 0 ppm (control), respectively.

Enhanced head size, weight and yield in Mel treated broccoli may be attributed to improved photosynthesis, plant growth and vigour (Mansha Gul et al., 2018, 2021) that might have resulted in a better development of source leaves which synthesized and supplied more photosynthates to the sink for the formation of broccoli heads. Similar trend has also been noticed by Sermenli et al (2011) for main head size in broccoli.

\section{Food reserves and pigmentation}

Findings of the study (Table 2) showed that application of Mel $80 \mathrm{ppm}$ resulted in maximum levels of sugar and protein contents $(129.0$ and $88.0 \mu \mathrm{g} / \mathrm{ml})$, respectively of broccoli 
sprouts. Mel 60ppm was established as the second best treatment in terms of sugar and protein content $(125.4$ and $81.1 \mu \mathrm{g} / \mathrm{ml})$ followed by $40 \mathrm{ppm}(118.2$ and $79.5 \mu \mathrm{g} / \mathrm{ml})$ and $20 \mathrm{ppm}(111.3$ and $73.8 \mu \mathrm{g} / \mathrm{ml})$ of Mel compared to minimum sugar and protein contents (105.0 and 68.0) in control. Perusal of the data again pointed out that amount of both chlorophyll and carotenoid present in head of control plants ( 0.31 and $0.012 \mathrm{mg} / \mathrm{gFW}$ ) was better when sprayed with different concentrations of melatonin wherein Mel 60ppm was established as the most superior treatment and produced the highest amount of chlorophyll and carotenoid content $(0.79$ and $0.028 \mathrm{mg} / \mathrm{gFW})$. Mel $80 \mathrm{ppm}$ was proved as the next superior treatment in producing these compounds ( 0.64 and $0.021 \mathrm{mg} / \mathrm{gFW})$. Mel $40 \mathrm{ppm}$ and Mel $20 \mathrm{ppm}$ followed the above treatments in order and resulted in chlorophyll and carotenoid content of 0.55 and 0.017 and 0.42 and $0.014 \mathrm{mg} / \mathrm{g} . \mathrm{FW}$, respectively.

An elevated level of fruit sugar and protein contents has been reported by Debnath et al. (2018) in tomato. Yang et al., (2019) stated that melatonin induced significant accumulations of fructose, glucose and sucrose in apple through the down regulation of $F R K 2$ expression, a gene encoding fructokinase (FRK).

Increased amount of chlorophyll due to foliar application of Mel may be attributed to its role in delaying $\mathrm{Chl}$ breakdown

and simultaneously accelerating its de novo synthesis (Szafranska et al., 2017). Tal et al., (2011) stated that melatonin can also preserve chlorophyll content in plants by the radical rummaging activity of indoleamine of melatonin. Melatonin-induced increase in carotenoid content has been attributed to the expression of genes related to carotene biosynthesis (Sun et al., 2020). Results of the present study that increasing chlorophyll contents also showed a similar trend with respect to carotenoid also conforms the findings of earlier research (Ranmalbhai, 2014).

\section{Antioxidant and membrane characters}

Analysis of different antioxidant and membrane characters (phenol, total antioxidant, MDA and MSI) of broccoli sprouts under the influence of foliar spray of Mel (Table 3 ) indicated that the Mel $60 \mathrm{ppm}$ resulted in highest value of phenol content in broccoli sprouts $(178.2 \mathrm{mg} / 100 \mathrm{~g} \mathrm{DW})$ compared to the lowest value $(151.9 \mathrm{mg} / 100 \mathrm{~g} \mathrm{DW})$ in control. The highest value of phenol in Mel $60 \mathrm{ppm}$ was followed by Mel 80 ppm (170.1 mg/100 g DW), Mel 40 ppm (160.9 mg/100 g DW) and Mel 20 ppm (160.9 mg/100g DW). Data regarding total antioxidant showed that $\mathrm{Mel} 80 \mathrm{ppm}$ resulted in highest value of antioxidant (365.4 mg GAE $100 \mathrm{~g} \mathrm{DW}$ ). However, the values of antioxidant recorded with Mel 40 ppm (358.2 mg GAE 100g DW) as well with Mel 60 ppm (362.3 mg GAE Table 1: Effect of foliar application of melatonin (Mel) onagronomic characters of broccoli head

\begin{tabular}{lcccc}
\hline Treatments & Polar diameter $(\mathrm{cm})$ & Equatorial diameter $(\mathrm{cm})$ & Head weight $(\mathrm{g})$ & Yield $(\mathrm{kg} / \mathrm{plot})$ \\
\hline Mel $0 \mathrm{ppm}$ & 7.1 & 6.5 & 199.9 & 1.5 \\
Mel $20 \mathrm{ppm}$ & 9.7 & 6.9 & 208.1 & 1.6 \\
Mel $40 \mathrm{ppm}$ & 10.1 & 8.1 & 221.5 & 1.7 \\
Mel $60 \mathrm{ppm}$ & 11.6 & 10.4 & 240.4 & 1.9 \\
Mel $80 \mathrm{ppm}$ & 10.7 & 9.5 & 233.8 & 1.8 \\
CD $(\mathrm{p} \leq 0.05)$ & 1.0 & 1.1 & 0.1 \\
\hline
\end{tabular}

Table 2: Effect of foliar application of melatonin (Mel) onhead chlorophyll and carotenoid content of broccoli.

\begin{tabular}{|c|c|c|c|c|}
\hline Treatments & $\begin{array}{c}\text { Total sugars } \\
(\mu \mathrm{g} / \mathrm{ml})\end{array}$ & $\begin{array}{l}\text { Soluble proteins } \\
\qquad(\mu \mathrm{g} / \mathrm{ml})\end{array}$ & $\begin{array}{l}\text { Chlorophyll } \\
\left(\mathrm{mg} \mathrm{g}^{-1} \mathrm{FW}\right)\end{array}$ & $\begin{array}{l}\text { Carotenoids } \\
\left(\mathrm{mg} \mathrm{g}^{-1} \mathrm{FW}\right)\end{array}$ \\
\hline Mel 0 ppm & 105.0 & 68.0 & 0.31 & 0.012 \\
\hline Mel 20 ppm & 111.3 & 73.8 & 0.42 & 0.014 \\
\hline Mel 40 ppm & 118.2 & 79.5 & 0.55 & 0.017 \\
\hline Mel 60 ppm & 125.4 & 81.1 & 0.79 & 0.028 \\
\hline Mel 80 ppm & 129.0 & 88.0 & 0.64 & 0.021 \\
\hline$C D(p \leq 0.05)$ & 3.1 & 6.01 & 0.10 & 0.001 \\
\hline
\end{tabular}

Figures in parenthesis are squire root transformed data for the purpose of statistical analysis.

Table 3: Effect of foliar application of melatonin (Mel) on antioxidant and membrane characters of broccoli sprouts.

\begin{tabular}{lccr}
\hline Treatments & $\begin{array}{c}\text { Phenols } \\
(\mathrm{mg} / 100 \mathrm{~g} \mathrm{DW})\end{array}$ & $\begin{array}{c}\text { Total antioxidant } \\
(\mathrm{mg} \mathrm{GAE} \mathrm{100} \mathrm{g} \mathrm{DW})\end{array}$ & $\begin{array}{c}\text { MSI } \\
(\%)\end{array}$ \\
\hline Mel $0 \mathrm{ppm}$ & 151.9 & 319.7 & 0.21 \\
Mel $20 \mathrm{ppm}$ & 160.9 & 336.8 & 0.18 \\
Mel $40 \mathrm{ppm}$ & 166.4 & 358.2 & $32.22(5.68)$ \\
Mel $60 \mathrm{ppm}$ & 178.2 & 362.3 & 3.16 \\
Mel $80 \mathrm{ppm}$ & 170.1 & 365.4 & 0.12 \\
CD $(\mathrm{p} \leq 0.05)$ & 5.8 & 7.9 & $45.38(6.96)$ \\
\hline
\end{tabular}


$100 \mathrm{~g} \mathrm{DW}$ ) were found at par with Mel $80 \mathrm{ppm}$. These values were significantly followed by Mel 20 ppm (336.8 mg GAE $100 \mathrm{~g} \mathrm{DW})$ while as untreated plants showed the minimum antioxidant value (319.7 $\mathrm{mg}$ GAE $100 \mathrm{~g} \mathrm{DW}$ ) than all other treatments. Perusal of the data further revealed that the amount of malondialdehyde (MDA) measured in the broccoli sprouts was found minimum $(0.12 \mu \mathrm{mol} \mathrm{MDA} / \mathrm{g} \mathrm{FW})$ with Mel 60ppm which was also at par $(0.13 \mu \mathrm{mol} \mathrm{MDA} / \mathrm{g} \mathrm{FW})$ with the plants treated with Mel $80 \mathrm{ppm}$. The minimum MDA value obtained was followed significantly in ascending order by Mel $40 \mathrm{ppm}(0.16 \mu \mathrm{mol}$ MDA/g FW $)$, Mel 20 ppm $(0.18 \mu$ $\mathrm{mol} \mathrm{MDA} / \mathrm{g} \mathrm{FW})$ and maximum $(0.21 \mu \mathrm{mol} \mathrm{MDA} / \mathrm{g} F W)$ in control. Measurement of antioxidant potential in terms of membrane stability index (MSI) revealed that Mel $80 \mathrm{ppm}$ exhibited highest MSI (46.22\%) which was found at par with MSI value of $45.38 \%$ under Mel 60 ppm treated plants. However, these values were significantly followed by Mel 40 ppm (39.56\%) and Mel 20 ppm (32.22\%) while the least value of MSI (27.16\%) was recorded with control.

The application of exogenous melatonin alleviated reactive oxygen species and cell damage induced by means of repairing mitochondria (Sharif et al., 2018). Melatonin is known to play an important role in the detoxification of reactive oxygen and free radicals and functions as an antioxidant in living organisms. As a broad-spectrum antioxidant, melatonin can directly eliminated ROS and the subsequent products, its derivatives, AFMK (N1-acetyl-N2formyl-5-methoxyknuramine) and AMK (N1-acetyl-5methoxykynuramine), can also scavenge ROS and further terminate the cascade reaction of lipid peroxidation. Thus, one molecule of melatonin may eventually scavenge ten molecules of radicals at least. Melatonin treatment can markedly decreased the content of ROS and thus alleviate oxidative damages induced by the excessive ROS accumulation (Huang et al., 2019).

\section{CONCLUSION}

Foliar application of Mel (@60 ppm) at 30 days after transplanting resulted in significant improvement in head diameter and head weight. This treatment also resulted in highest chlorophyll and carotenoid contents in broccoli sprouts. However, total sugar and protein contents of broccoli sprouts were significantly highest with Mel 80 ppm.A significantly highest level of phenols and MSI were evident with Mel $60 \mathrm{ppm}$ while as the level of total antioxidants was at par with Mel 60 and $80 \mathrm{ppm}$. An inverse trend was recorded in case of MDA level of broccoli sprouts.

\section{REFERENCES}

Arnao, M.B. and Hernández-Ruiz, J. (2014). Melatonin: Plant growth regulator and/or biostimulator during stress? Trends in Plant Science. 19(12): 789-797. https:// doi.org/10.1016/j.tplants.2014.07.006.

Bradford, M.M. (1976). A rapid and sensitive method for the quantitation of microgram quantities of protein utilizing the principle of protein-dye binding. Analytical Biochemistry. 72: $248-254$.
Bray, H.G. and Thorpe, W.V. (1954). Analysis of phenolic compounds of interest in metabolism. Methods of Biochemical Analysis. 52: 1-27.

Buck, P.A. (1956). Origin and taxonomy of broccoli. Economic Botany. 10: 250-253.

Cakmak, I. and Hors, W.J., (1991). Effect of aluminum on lipid peroxidation, superoxide dismutase, catalase and peroxidase activities in root tips of soybean (Glycine max). Physiologia Plantarum. 83: 463-468

Debnath, B., Hussain, M., Li, M., Lu, X. and Qiu, D. (2018). Exogenous melatonin improves fruit quality features, health promoting antioxidant compounds and yield traits in tomato fruits, Molecules. 23(8):1868. https://doi.org/ 10.3390molecules 23081868

Dubois, M., Gilles, K.A., Harmilton, J.K., Rebers, P.A. and Smith, F. (1956). Colorimetric method for determination of sugars and related substances. Analytical Chemistry. 28: 350-356.

Gray, A. R. (1982). Taxonomy and evolution of broccoli (Brassica oleracea var. italica) Economic Botany. 36: 397-410.

Huang, B., Chen, Y.E., Zhao, Y.Q., Ding, C.B., Liao, J.Q., Hu, C., Zhou, L.J., Zhang, Z.W., Yuan, S. and Yuan, M. (2019). Exogenous melatonin alleviates oxidative damages and protects photosystem II in maize seedlings under drought stress. Frontiers in Plant Science. 10: 677. doi: 10.3389/fpls.2019.00677.

Lee, H.Y., Byeon, Y., Tan, D.X., Reiter, R.J. and Back, K. (2015) Arabidopsis serotonin $\mathrm{N}$-acetyltransferase knockout mutant plants exhibit decreased melatonin and salicylic acid levels resulting in susceptibility to an avirulent pathogen. Journal of Pineal Research. 58 (3): 291-299.

Mansha Gul, Khan, F.A., Wan,i S.A., Bhat, S.A., Mir, S.A., Malik, A.A., Kumar, A. and Narayan, S. (2018). Foliar application of melatonin modulates the growth and photosynthetic pigments in broccoli cv. Palam Samridhi. SKUAST Journal of Research. 20 (2): 193-198.

Mansha Gul, Khan, F.A., Wani, S.A., Bhat, S.A., Mir, S.A., Malik, A.A., Kumar, A., Narayan S. Moinuddin, Fasil Fayaz and Lone, S.A. (2021). Effects of foliar application of melatonin on gas exchange and certain biochemical characteristics broccoli cv. Palam Samridhi. Journal of Applied and Natural Science. 13(2): 791-797.

Owis, A.I. (2015). Broccoli, the green beauty - A Review. Journal of Pharmaceutical Sciences and Research. 7: 696-703

Pandi-Perumal, S.R., Srinivasan, V., Maestroni, G.J.M., Cardinaldi, D.P., Poeggeler, B. and Hardeland, R. (2006). Melatonin: nature's most versatile biological signal? The FEBS Journal. 273: 2813-38.

Panse, V.G. and Sukhatme, P.V. (1967). Statistical Methods for Agricultural Workers, $2^{\text {nd }}$ Edition, Indian Council of Agricultural Research, New Delhi.

Premachandra, G. S., Saneoka, H. and Ogata (1990). Cell membrane stability an indicator of drought tolerance as affected by applied $\mathrm{N}$ in soybean. Journal of Agricultural Science. 115: 63-66.

Prieto, P., Pineda, M. and Aguilar, M. (1999). Spectrophotometric quantitation of antioxidant capacity through the formation of a phosphomolybdenum complex: Specific application to the determination of vitamin E. Analytical. Biochemistry. 269: 337-341. 
Effects of Foliar Application of Melatonin on Head Yield and Quality of Broccoli cv. Palam Samridhi

Ranmalbhai, J.A. (2014). Morphological, biochemical and molecular characterization of okra cultivars (Abelmoscus esculentus L.).M.Sc. thesis submitted to Department of Biochemistry, B.A.College of Agriculture, Anand Agriculture University, Anand, (Gujrat), India.

Sairam, R.K. (1994). Effect of moisture stress on physiological activities of two contrasting wheat genotypes. Indian Journal of Experimental Biology. 32: 594-597.

Sermenli, T., Mavi, K. and Yilmaz, S. (2011). Determination of transplanting dates of broccoli (Brassica oleraceae var italic olenk) under Antakya conditions. Journal of Animal and Plant Science. 21: 838-841.

Sharif, R., Xie, C., Zhang , H., Arnao, M.B., Ali, M., Ali, Q., Muhammad, I., Shalmani, A., Nawaz, M.A., Chen, P. and Li, Y. (2018). Melatonin and its effects on pant systems-review. Molecules. 23 (2352): 1-20.

Sun, Q., Liu, L., Zhang, L., Lv, H., He, Q., Guo, L., Zhang, X., He, H., Ren, S., Zhang, N., Zhao, B. and Guo, Y. (2020). Melatonin promotes carotenoid biosynthesis in an ethylenedependentmanner in tomato fruits. Plant Science. 298:1-9.

Szafranska, K., Reiter, R.J. and Posmyk, M.M. (2017). Melatonin improves the photosynthetic apparatus in pea leaves stressed by paraquat via chlorophyll breakdown regulation and its accelerated de novo synthesis. Frontiers in Plant Science, 8: 878. doi: 10.3389/fpls.2017.00878.
Tal, O., Haim, A., Harel, O., Gerchman, Y. (2011). Melatonin as an antioxidant and its semi lunar rhythm in green macro alga Ulva sp. Journal of Experimental Botany. 62: 1903-1910.

Weeda S, Zhang N, Zhao X, Ndip G, Guo Y, et al. (2014) Arabidopsis transcriptome analysis reveals key roles of melatonin in plant defense systems. PLoS ONE 9(3): e93462. doi:10.1371/ journal.pone.0093462.

Wolf, S., Zikeli, S., Fleck, M., Graeff-Hoenninger, S., Clauepein, W. (2014), Open pollinated broccoli genotypes: Agronomic parameters and sensory attributes. In Building Organic Bridges $-A$ proceedings of the $4^{\text {th }}$ ISOFAR Scientific Conference at the Organic World Congress 2014 (Ed. Rahmann, Gerold), 2014, 2. 427 - 30.

Yang, J., Zhang, C., Wang, Z., Sun, S., Zhan, R., Zhao, Y., Ma, B., Ma,F. and Li, M. (2019). Melatonin-mediated sugar accumulation and growth inhibition in apple plants involves down-regulation of fructokinase 2 expression and activity. Frontiers in Plant Science, 10: 150. doi: 10.3389/fpls. 2019.00150 . 